\title{
PERSEPSI MAHASISWA TERHADAP LAYANAN KEGIATAN MAHASISWA S1 KEPERAWATAN DI FAKULTAS KEPERAWATAN USU
}

\author{
Perception of Student Services S1 Nursing \\ Student Activity USU in Nursing Faculty \\ Syaiful \\ Dosen Tetap Yayasan Akper Kesdam I/BB Medan \\ email : syaiful_trovas20@yahoo.com
}

\begin{abstract}
Abstrak
Layanan kegiatan mahasiswa yang merupakan salah satu evaluasi internal dalam penyelenggaraan program studi pendidikan tinggi. Hasilnya dapat digunakan untuk mendukung pencapaian kompetensi mahasiswa khususnya untuk pengembangan soft skill. Penelitian deskriptif eksploratif dilakukan untuk mengetahui persepsi mahasiswa terhadap layanan kegiatan mahasiswa S1 Keperawatan di Fakultas Keperawatan Universitas Sumatera Utara. Sampel adalah mahasiswa S1 reguler semester 3, 5 dan 7 dengan menggunakan tehnik cluster sampling. Pengumpulan data menggunakan kuesioner yang melibatkan 80 responden mahasiswa S1 Keperawatan reguler. Hasilnya menunjukan $68,7 \%$ mempunyai persepsi yang tidak baik terhadap lima layanan yaitu layanan bimbingan dan konseling, layanan minat dan bakat, layanan pembinaan soft skills, layanan beasiswa dan layanan kesehatan. Direkomendasikan untuk meningkatkan layanan kegiatan mahasiswa di Fakultas Keperawatan Universitas Sumatera Utara yang mencakup layanan bimbingan dan konseling, minat dan bakat dan pembinaan soft skills yang saat ini belum ada.
\end{abstract}

Kata Kunci : Persepsi, Layanan Kegiatan, Mahasiswa S1 Reguler

\begin{abstract}
Student activities Services is one of internal evaluation in higher education study program operations. The results can be used to support the achievement of student competencies in particular for the development of soft skills. Descriptive exploratory study was conducted to determine students' perceptions of bachelor nursing students aktivities services at the Faculty of Nursing University of Sumatera Utara. Bachelor nursing students at the semester of third, fifth and sevents by using a cluster sampling technique. Data Collection data using a questionnaire that involved 80 respondents. The results showed that $68.7 \%$ do not have a good perception of the five services that guidance and counseling, service interests and talents, soft skills training services, health care services and scholarships. Recommended to improve student services in the faculty of Nursing University of Sumatera Utara which includes guidance and counseling services, interests and talents and development of soft skills that do not yet exist.
\end{abstract}

Keywords : Perception, Event Services, Student S1 Regular

\section{Pendahuluan}

\section{Latar Belakang}

Pendidikan Tinggi adalah jenjang pendidikan setelah pendidikan menengah yang mencakup program diploma, sarjana, program magister, program doktor, dan program profesi, serta program spesialis, yang diselenggarakan oleh Perguruan Tinggi berdasarkan kebudayaan bangsa Indonesia. (UU RI N0.12 Tahun 2012 tentang Pendidikan Tinggi Bab I ayat (2).

Perguruan Tinggi sebagai lembaga yang menyelenggarakan Pendidikan Tinggi penelitian dan pengabdian kepada masyarakat, harus memiliki otonomi dalam mengelola sendiri lembaganya. Hal ini diperlukan agar dalam pengembangan ilmu pengetahuan dan teknologi di Perguruan Tinggi berlaku kebebasan akademik dan mimbar akademik, serta otonomi keilmuan. Dengan demikian Perguruan Tinggi dapat mengembangkan budaya akademik bagi Sivitas Akademika yang berfungsi sebagai komunitas ilmiah yang berwibawa dan mampu berinteraksi yang mengangkat martabat bangsa Indonesia dalam pergaulan 
internasional. Perguruan Tinggi sebagai garda terdepan dalam mencerdaskan kehidupan bangsa, dengan mengembangkan Ilmu Pengetahuan dan Teknologi untuk memajukan kesejahteraan umum dan keadilan sosial bagi seluruh rakyat Indonesia. (UU DIKTI, Tahun 2012)

Menurut UU RI Nomor 12 Tahun 2012 tentang Pendidikan Tinggi BAB I Pasal 14 ayat : (1) Mahasiswa mengembangkan bakat, minat, dan kemampuan dirinya melalui kegiatan kokurikuler dan ekstrakurikuler sebagai bagian dari proses Pendidikan ; (2) Kegiatan kokurikuler dan ekstrakurikuler sebagaimana dimaksud pada ayat (1), dapat dilaksanakan melalui organisasi kemahasiswaan ; (3) Ketentuan lain mengenai kegiatan kokurikuler dan ekstrakurikuler sebagaimana dimaksud pada ayat (1) diatur dalam statuta Perguruan Tinggi.

Kegiatan Kurikuler ada 4 macam terdiri dari : (1) Ada tiga bentuk kegiatan kurikuler, yaitu, intrakurikuler, kokurikuler dan ekstrakurikuler. Kegiatan ini sangat penting artinya bagi pelaksanaan kegiatan belajar mengajar, penilaian, dan system kredit ; (2) Kegiatan intrakurikuler dilaksanakan sesuai dengan struktur program. Pelaksanaannya di sekolah dan seluruh kegiatannya dinilai ; (3) Kegiatan kokurikuler di luar struktur program. Tujuannya untuk memberikan perluasan dan pendalaman terhadap apa yang telah dipelajarinya dalam kegiatan intrakurikuler. Kegiatan kokurikuler ini wajib dinilai ; (4) Kegiatan ekstrakurikuler terutama ditujukan untuk keperluan pembinaan bakat dan prestasi siswa. Kegiatan ini jdilaksanakan di luar sekolah dan tidak dinilai. Apabila pembimbing perlu mengadakan penilaian hanya terbatas pada upaya penguatan (reinforcement). (Ihsan, 2005)

Dalam rangka akreditasi program studi/perguruan tinggi yang bertujuan, terutama untuk menilai dan memberikan jaminan mutu program dan satuan pendidikan tinggi (quality assessment and assurance), layanan kegiatan mahasiswa yang merupakan evaluasi internal pada program dan satuan pendidikan tinggi (program studi dan perguruan tinggi), adalah langkah pertama yang hasilnya dapat digunakan untuk berbagai maksud. Hasil layanan kegiatan mahasiswa dapat digunakan untuk memutakhirkan pangkalan data program studi/perguruan tinggi dalam bentuk profil yang komprehensif, perencanaan, strategi pengembangan dan perbaikan program studi/perguruan tinggi secara berkelanjutan, penjaminan mutu internal program studi/perguruan tinggi, dan untuk mempersiapkan evaluasi eksternal atau akreditasi. Salah satu tahap dari proses akreditasi ialah melakukan asesmen lapangan untuk verifikasi, validasi, dan melengkapi data dan informasi yang disajikan dalam borang, serta melakukan penilaian lapangan di program studi yang bersangkutan. Akses layanan kemahasiswaan dan pengembangan minat dan bakat yang diusahakan program studi berupa akses kepada fasilitas pusat kegiatan mahasiswa, asrama, layanan kesehatan, beasiswa, dan kegiatan ekstra kurikuler (BAN PT, 2008).

Tujuan Umum mengetahui gambaran persepsi mahasiswa terhadap layanan kegiatan mahasiswa S1 Keperawatan di Fakultas Keperawatan USU.

Tujuan Khusus : (a). Untuk mengetahui gambaran persepsi mahasiswa semester $3 \mathrm{~S} 1$ Keperawatan terhadap layanan mahasiswa; (b). Untuk mengetahui gambaran persepsi mahasiswa semester 5 S1 Keperawatan terhadap layanan mahasiswa; (c). Untuk mengetahui gambaran persepsi mahasiswa semester 7 S1 Keperawatan terhadap layanan mahasiswa.

\section{Metode}

Penelitian yang menyajikan konsep atau teori dalam bentuk kerangka konsep penelitian. Pembuatan kerangka konsep ini mengacu pada masalah-masalah (bagianbagian) yang akan diteliti atau berhubungan dengan penelitian dan dibuat dalam bentuk diagram (Aziz, 2002)

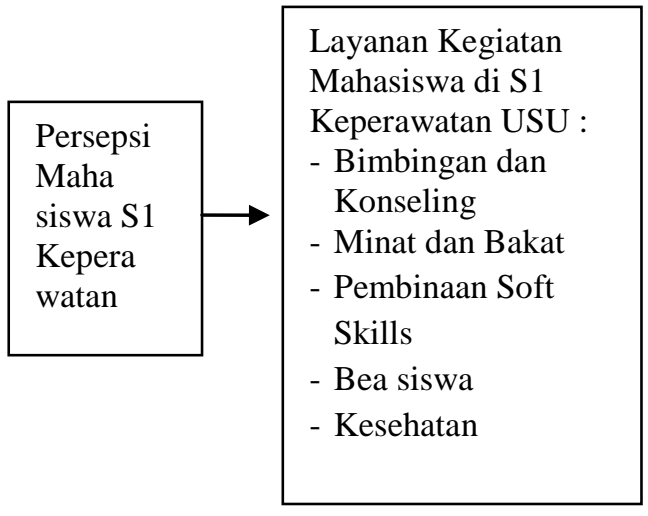

Gambar 2. Kerangka Penelitian Persepsi mahasiswa terhadap layanan kegiatan mahasiswa S1 Keperawatan di Fakultas Keperawatan USU. 
Penelitian dalam studi ini menggunakan desain deskriptif eksploratif yaitu penelitian untuk menemukan hal yang baru, yang bertujuan untuk mengetahui persepsi mahasiswa terhadap layanan kegiatan mahasiswa S1 Keperawatan di Fakultas Keperawatan USU.

Populasi adalah keseluruhan subjek penelitian, populasi dalam penelitian ini adalah mahasiswa reguler program sarjana di Fakultas Keperawatan USU yang aktif pada semester ganjil T.A. 2013/2014. Dari Sub Bag Akademik Fakultas Keperawatan USU tercatat jumlah 394 orang terdiri dari 3 kelas yaitu semester 3, 5 dan 7 .

Penelitian sampel adalah penelitian yang dilakukan pada sampel yang dipilih dengan teknik yang tertentu yang hasilnya dapat digeneralisasi. Yang dimaksud dengan digeneralisasikan di sini adalah hasil penelitiannya dapat ditetapkan pada populasi atau populasi lain yang memiliki karakteristik yang sama. Penelitian sampel yang menjadi sumber datanya adalah sampel. (Hartono, 2010).

Sampel sebanyak 80 orang yang diantaranya memiliki kategori kelas yang terdiri dari 3 kelas yaitu Kelas Reguler semester 3 berjumlah 138 orang, semester 5 berjumlah 129 orang, semester 7 berjumlah 127 orang. Pengambilan sampel dalam penelitan ini dengan cara cluster sampling yaitu teknik pengambilan sampel di mana pemilihan mengacu pada kelompok bukan pada individu. Penelitian ini dilaksanakan di Fakultas Keperawatan USU yang dilaksanakan mulai bulan Nopember 2013. Persepsi mahasiswa terhadap layanan kegiatan mahasiswa S1 Keperawatan di Fakultas Keperawatan Universitas Sumatera Utara. Instrumen dalam penelitian ini adalah kuesioner terdiri dari 2 bagian yaitu, data demografi dan persepsi.

Hasil

Pada bab ini diuraikan hasil penelitian serta pembahasan mengenai persepsi mahasiswa terhadap layanan kegiatan mahasiswa S1 Keperawatan di Fakultas Keperawatan Universitas Sumatera Utara.

\section{Hasil Penelitian}

Penelitian ini telah dilaksanakan mulai dari bulan Nopember s/d Desember 2013. Penelitian ini melibatkan 80 responden dengan menggunakan pengukuran cluster sampling di mana terdapat tiga kelompok yaitu mahasiswa semester 3 dengan jumlah 26 orang responden, mahasiswa semester 5 dengan jumlah 26 orang responden dan mahasiswa semester 7 dengan jumlah 28 orang responden diberikan beberapa layanan kegiatan mahasiswa S1 Keperawatan di Fakultas Keperawatan Universitas Sumatera Utara.

Hasil penelitian ini memaparkan karakteristik demografi responden dan persepsi mahasiswa terhadap layanan kegiatan mahasiswa S1 Keperawatan di Fakultas Keperawatan Universitas Sumatera Utara.

\section{Karakteristik Demografi Responden}

Responden penelitian ini adalah setiap orang yang bersedia menjadi responden dan sedang belajar di Program Studi Ilmu Keperawatan Fakultas Keperawatan Universitas Sumatera Utara dan masuk melalui program reguler yaitu yang masih duduk di semester 3, 5 dan 7 . Data demografi responden yaitu umur, jenis kelamin, agama, tempat tinggal selama pendidikan dan lokasi tempat tinggal dengan fakultas keperawatan. Dapat dilihat dari Tabel 5.1 sebagai berikut:

\begin{tabular}{|c|c|c|}
\hline $\begin{array}{l}\text { Tabel 5.1 Di } \\
\text { Karakteristik } \\
\text { Reguler di } \\
\text { Universitas Sun }\end{array}$ & $\begin{array}{l}\text { nogi } \\
\text { nografi } \\
\text { akultas } \\
\text { era Utara }\end{array}$ & $\begin{array}{r}\text { Frekuensi } \\
\text { ahasiswa } \mathrm{S1} \\
\text { Ceperawatan }\end{array}$ \\
\hline $\begin{array}{l}\text { Karakteristik } \\
\text { Demografi }\end{array}$ & $\begin{array}{l}\text { Frekuen } \\
\text { si }\end{array}$ & $\begin{array}{l}\text { Persentase } \\
(\%)\end{array}$ \\
\hline Usia & & \\
\hline 18 tahun & 4 & 5,0 \\
\hline 19 tahun & 20 & 25,0 \\
\hline 20 tahun & 36 & 45,0 \\
\hline 22 tahun & 3 & 3,7 \\
\hline Jenis Kelamin & & \\
\hline Laki-Laki & 20 & 25,0 \\
\hline Perempuan & 60 & 75,0 \\
\hline Agama & & \\
\hline Islam & 44 & 55,0 \\
\hline $\begin{array}{l}\text { Kristen } \\
\text { Protestan }\end{array}$ & 31 & 38,7 \\
\hline Katolik & 5 & 6,3 \\
\hline Hindu & - & - \\
\hline Budha & - & - \\
\hline
\end{tabular}

\section{Tempat tinggal \\ selama}

pendidikan

Tinggal bersama 21

orang tua

Kontrak 
rumah/kost

bersama dengan

dua atau lebih

orang lain

$$
\text { Kontrak }
$$

16

20,0

rumah/kost

sendiri

\section{Lokasi tempat}

tinggal dengan

Fakultas

Keperawatan

Dekat dan dapat

ditempuh

$25 \quad 32,3$

kaki

\begin{tabular}{lll}
\hline $\begin{array}{l}\text { Karakteristik } \\
\text { Persepsi }\end{array}$ & $\begin{array}{l}\text { Frekuen } \\
\text { si }\end{array}$ & $\begin{array}{l}\text { Persentase } \\
(\mathbf{\%})\end{array}$ \\
\hline Baik & 3 & 11.5 \\
Tidak baik & 23 & 88.5 \\
\hline Jumlah & $\mathbf{2 6}$ & $\mathbf{1 0 0}$ \\
\hline $\begin{array}{l}\text { Dekat tetapi } \\
\text { harus naik }\end{array}$ & 29 & 36,2 \\
$\begin{array}{l}\text { kendaraan tetapi } \\
\text { Jauh } 26\end{array}$ & \\
$\begin{array}{l}\text { masih di dalam } \\
\text { kota Medan }\end{array}$ & & 32,5 \\
\hline
\end{tabular}

Berdasarkan Tabel 5.1 Distribusi Frekuensi Karakteristik Demografi mahasiswa S1 Reguler Keperawatan berdasarkan usia mayoritas berusia 20 tahun sebanyak 36 responden (45\%), berdasarkan jenis kelamin mayoritas perempuan sebanyak 60 responden $(75 \%)$, berdasarkan agama mayoritas memiliki agama Islam sebanyak 44 responden $(55 \%)$, berdasarkan tempat tinggal selama pendidikan di Fakultas Keperawatan Universitas Sumatera Utara mayoritas kontrak rumah/kost bersama dua atau lebih orang lain sebanyak 43 responden $(53 \%)$ serta dilihat dari lokasi tempat tinggal dengan Fakultas Keperawatan mayoritas dekat tetapi harus naik kendaraan sebanyak 29 responden (36 $\%)$.

Tabel 5.2 Tabel Karakteristik Persepsi Mahasiswa/i Semester 3 S1 Reguler Terhadap Layanan Kegiatan Mahasiswa S1 Keperawatan di Fakultas Keperawatan Universitas Sumatera Utara $(n=26)$

\begin{tabular}{lll}
\hline $\begin{array}{l}\text { Karakteristik } \\
\text { Persepsi }\end{array}$ & Frekuensi & $\begin{array}{l}\text { Persentase } \\
(\%)\end{array}$ \\
\hline Baik & 14 & 53.8 \\
Tidak Baik & 12 & 46.2 \\
\hline Jumlah & $\mathbf{2 6}$ & $\mathbf{1 0 0}$ \\
\hline
\end{tabular}

Setelah pengumpulan data dilakukan dengan pengisian kuesioner oleh responden untuk mengidentifikasi persepsi mahasiswa semester 3 berdasarkan tabel 5.2 tentang Persepsi Mahasiswa Terhadap Layanan Kegiatan Mahasiswa S1 Keperawatan di Fakultas Keperawatan Sumatera Utara mayoritas persepsi mahasiswa/i baik terhadap layanan kegiatan mahasiswa S1 Keperawatan di Fakultas Keperawatan Sumatera Utara sebanyak 14 orang responden $(53,8 \%)$.

Tabel 5.3 Tabel Karakteristik Persepsi Mahasiswa Semester 5 S1 Reguler Terhadap Layanan

Kegiatan Mahasiswa S1 Keperawatan di Fakultas Keperawatan Universitas Sumatera Utara $(n=26)$

Setelah pengumpulan data dilakukan dengan pengisian kuesioner oleh responden untuk mengidentifikasi persepsi mahasiswa semester 5 berdasarkan tabel 5.3 tentang Persepsi Mahasiswa Terhadap Layanan Kegiatan Mahasiswa S1 Keperawatan di Fakultas Keperawatan Sumatera Utara mayoritas memiliki persepsi tidak baik terhadap layanan kegiatan mahasiswa S1 Keperawatan di Fakultas Keperawatan Sumatera Utara sebanyak 23 orang responden $(88.5 \%)$.

Tabel 5.4 Tabel Karakteristik $\begin{array}{lllll}\text { Persepsi Mahasiswa Semester } & 7 & \text { S1 }\end{array}$ Reguler Terhadap Layanan Kegiatan Mahasiswa S1 Keperawatan di Fakultas Keperawatan Universitas Sumatera Utara $(\mathrm{n}=28)$

\begin{tabular}{lll}
\hline $\begin{array}{l}\text { Karakteristik } \\
\text { Persepsi }\end{array}$ & Frekuensi & $\begin{array}{l}\text { Persentase } \\
(\boldsymbol{\%})\end{array}$ \\
\hline Baik & 8 & 28.6 \\
Tidak Baik & 20 & 71.4 \\
\hline Jumlah & $\mathbf{2 8}$ & $\mathbf{1 0 0}$ \\
\hline
\end{tabular}

Setelah pengumpulan data dilakukan dengan pengisian kuesioner oleh responden untuk mengidentifikasi persepsi mahasiswa semester 7 berdasarkan tabel 5.4 tentang 
Persepsi Mahasiswa Terhadap Layanan Kegiatan Mahasiswa S1 Keperawatan di Fakultas Keperawatan Sumatera Utara mayoritas memiliki persepsi tidak baik terhadap layanan kegiatan mahasiswa S1 Keperawatan di Fakultas Keperawatan Sumatera Utara sebanyak 20 orang responden $(71.4 \%)$.

\section{Tabel 5.5 Tabel Karakteristik} Persepsi Mahasiswa S1 Reguler Terhadap Layanan Kegiatan Mahasiswa S1 Keperawatan di Fakultas Keperawatan Universitas Sumatera Utara

\begin{tabular}{lll}
\hline $\begin{array}{l}\text { Karakteristik } \\
\text { Persepsi }\end{array}$ & Frekuensi & $\begin{array}{l}\text { Persentase } \\
(\boldsymbol{\%})\end{array}$ \\
\hline Baik & 25 & 31.3 \\
Tidak Baik & 55 & 68.7 \\
\hline Jumlah & $\mathbf{8 0}$ & $\mathbf{1 0 0}$ \\
\hline
\end{tabular}

Setelah pengumpulan data dilakukan dengan pengisian kuesioner oleh responden untuk mengidentifikasi persepsi mahasiswa S1 reguler berdasarkan tabel 5.5 tentang Persepsi Mahasiswa S1 Terhadap Layanan Kegiatan Mahasiswa S1 Keperawatan di Fakultas Keperawatan Sumatera Utara mayoritas memiliki persepsi tidak baik terhadap layanan kegiatan mahasiswa S1 Keperawatan di Fakultas Keperawatan Sumatera Utara sebanyak 55 orang responden $(68,7 \%)$.

\section{Pembahasan}

Dalam pembahasan ini peneliti mencoba menjawab pertanyaan penelitian yaitu bagaimana persepsi mahasiswa terhadap layanan kegiatan mahasiswa S1 Keperawatan di Fakultas Keperawatan Universitas Sumatera Utara.

\section{Karakterikstik data Demografi Mahasiswa S1 Reguler di Fakultas Keperawatan Universitas Sumatera Utara}

Pada hasil penelitian akan diuraikan tentang gambaran demografi 80 responden terdiri dari mahasiswa semester 3, mahasiswa semester 5 dan mahasiswa semester 7. Berdasarkan karakteristik data demografi mahasiswa S1 Reguler Keperawatan berdasarkan usia mayoritas berusia 20 tahun sebanyak 36 responden (45 $\%)$. Di lihat dari hasil tersebut, menurut (Notoadmodjo, 2007) bahwa usia mempengaruhi daya tangkap dan pola pikirnya sehingga pengetahuan yang diperoleh akan semakin baik. Di mana usia dari 20 tahun memasuki tahap usia dewasa muda. Pada usia ini individu dituntut untuk mempelajari peran baru di tempat kerja, rumah dan masyarakat serta mengembangkan minat, nilai-nilai dan sikap yang terkait dengan peran tersebut.

Berdasarkan jenis kelamin mayoritas perempuan sebanyak 60 responden $(75 \%)$. Menurut Ahmadi dan Sholeh (2005) bahwa perempuan dewasa muda memiliki sikap hidup yaitu bersifat pasif dan menerima, cenderung untuk menerima perlindungan, minat tertuju kepada yang bersifat emosional dan konkret, berusaha mengikut dan menyenangkan orang tua. Berdasarkan sifatsifat yang mendasari kaum perempuan dewasa muda cenderung lebih muda menerima diri, menyadari kekurangan dan kelebihan yang dimilikinya. Dalam bersosialisasi juga untuk memasuki dunia interaksi memiliki teman yang menyebabkan mereka harus menyesuaikan diri dengan kelompok sebaya dan mengikutinya serta mulai memiliki rasa ketertarikan dengan teman berlawan jenis. Berdasarkan agama mayoritas memiliki agama Islam sebanyak 44 orang responden (55\%), berdasarkan tempat tinggal selama pendidikan di Fakultas Keperawatan Universitas Sumatera Utara mayoritas kontrak rumah/kost bersama dua atau lebih orang lain sebanyak 43 responden $(53,8 \%)$ serta di lihat dari lokasi tempat tinggal dengan Fakultas Keperawatan mayoritas dekat tetapi harus naik kendaraan sebanyak 29 responden $(36,2$ $\%)$.

Persepsi Mahasiswa Terhadap Layanan Kegiatan Mahasiswa S1 Keperawatan di Fakultas Keperawatan Universitas Sumatera Utara

Persepsi menunjukkan adanya kesesuaian reaksi terhadap stimulus. Persepsi merupakan proses diterimanya rangsang melalui panca indera yang dilalui oleh perhatian tentang hal yang diamati. Dengan persepsi seseorang dapat menyadari dan mengerti tentang apa yang ada disekitarnya. Pada penelitian ini mahasiswa semester 3 memiliki persepsi baik terhadap layanan kegiatan mahasiswa sebanyak 14 orang $(53,8 \%)$, mahasiswa semester 5 mayoritas memiliki persepsi tidak baik sebanyak 23 responden $(88.5 \%)$ dan mahasiswa semester 7 juga memiliki persepsi tidak baik sebanyak 20 responden $(71.4 \%)$ terhadap layanan kegiatan 
mahasiswa S1 Keperawatan di Fakultas Keperawatan Universitas Sumatera Utara. Menurut Rakhmat (2004) faktor-faktor fungsional yang menentukan persepsi seseorang berasal dari kebutuhan, pengalaman masa lalu dan hal-hal lain termasuk yang kita sebut sebagai faktorfaktor personal. Selanjutnya Rakhmat menjelaskan yang menentukan persepsi bukan jenis atau bentuk stimuli, tetapi karakteristik orang yang memberikan respon terhadap stimuli. Persepsi meliputi juga kognisi (pengetahuan), yang mencakup penafsiran objek, tanda dan orang dari sudut pengalaman yang bersangkutan (Gibson, 1986). Selaras dengan pernyataan tersebut Kreck, dkk dalam Sri Tjahjorini Sugiharto, (2001) mengemukakan bahwa persepsi seseorang ditentukan oleh dua faktor utama yakni pengalaman masa lalu dan faktor pribadi.

Pada umumnya semua responden memiliki persepsi tidak baik sebanyak 55 responden (68,7 \%). Menurut (Carpenito, 1995), bahwa tingkat pendidikan dapat mempengaruhi seseorang dalam melakukan tindakan, karena semakin tinggi tingkat pendidikan perawat maka semakin tinggi tingkat pengetahuannya dalam memberikan respon terhadap bentuk kegiatan atau tindakan yang akan dilakukan.

Persepsi dapat mempengaruhi tingkah laku seseorang terhadap objek dan situasi lingkungannya. Sementara tingkah laku seseorang juga dipengaruhi oleh keadaan sekitarnya, tingkah laku dan cara berpikir untuk menanggapi sesuatu peristiwa yang terjadi di lingkungannya. Persepsi akan berarti jika diperlihatkan dalam bentuk pernyataan, baik lisan maupun perbuatan. Meskipun demikian, terkadang apa yang dinyatakan dalam bentuk pernyataan perilaku yang terlihat belum tentu sesuai dengan persepsi yang asli. Menurut Walgito (2002 : 10) "Dalam kehidupan sehari-hari dapat dilihat bahwa perilaku dapat dibentuk, diperoleh, berubah melalui proses belajar". Dari uraian di atas dapat disimpulkan bahwa perilaku seseorang dapat dibentuk dan dipelajari dengan proses belajar.

Selain itu pengalaman dalam pendidikan juga dapat mempengaruhi persepsi seseorang, di mana pada penelitian ini ditemukan semakin naik tingkat pendidikannya, persepsi mahasiswa yang mempersepsikan bahwa layanan kegiatan mahasiswa yang baik semakin berkurang. Hal ini sesuai dengan pendapat Rahmat
(1992) dalam jurnal keperawatan Rufaidah (2005), bahwa pengalaman dapat mempengaruhi persepsi seseorang. Persepsi diartikan sebagai daya mengenal sesuatu yang hadir dalam sifatnya yang konkrit jasmaniah, bukan sifatnya batiniah, seperti benda, barang, kualitas, atau perbedaan antara dua hal atau lebih yang diperoleh melalui proses mengamatinya, mengetahui, dan mengartikan setelah panca inderanya mendapat rangsang. Persepsi yang benar adalah mampu mencerminkan apa yang sebenarnya (objektif), sedangkan persepsi yang tepat adalah yang serasi antara panca indera yang satu dengan yang lain atau orang yang satu dengan yang lain (Baihagi, 2005).

\section{Simpulan dan Saran}

Berdasarkan hasil penelitian dan pembahasan yang telah dilakukan maka dapat diambil kesimpulan dan saran sebagai berikut :

\section{Simpulan}

Hasil penelitian menunjukan bahwa sebagian besar mahasiswa semester 3 memiliki persepsi baik terhadap layanan kegiatan mahasiswa sebanyak 14 responden $(53,8 \%)$, mahasiswa semester 5 memiliki persepsi tidak baik sebanyak 23 responden $(88,5 \%)$ dan semester 7 memiliki persepsi tidak baik sebanyak 20 responden $(71,4 \%)$ terhadap layanan kegiatan mahasiswa S1 Keperawatan di Fakultas Keperawatan Universitas Sumatera Utara. Hal ini disebabkan karena semakin banyak kegiatan dan tugas yang dihadapi mahasiswa tingkat tinggi sehingga persepsi mereka terhadap layanan kegiatan mahasiswa tidak dapat terlaksana dengan baik dalam beberapa bentuk layanan yang seharusnya disediakan oleh fakultas kepada mahasiswa, yaitu mencakup layanan bimbingan dan konseling, minat dan bakat, pembinaan soft skills, beasiswa dan kesehatan.

\section{Rekomendasi terhadap pendidikan keperawatan}

Pada penelitian ini, dengan adanya minoritas persepsi mahasiswa terhadap layanan kegiatan mahasiswa S1 Keperawatan di Fakultas Keperawatan Universitas Sumatera Utara sampai dengan saat ini, belum memiliki sarana dan prasarana seperti layanan bimbingan dan konseling, minat dan bakat dan pembinaan 
soft skills sedangkan layanan bea siswa dan kesehatan sudah berjalan sesuai prosedur yang berlaku. Institusi agar membuat fasilitas layanan bimbingan dan konseling, layanan minat dan bakat, layanan pembinaan soft skills dengan baik dan untuk meningkatkan sumber daya manusia yang bermutu dan berkualitas.

\section{Saran}

Mahasiswa keperawatan khususnya program Reguler harus lebih banyak memiliki persepsi terhadap layanan kegiatan mahasiswa baik berupa beberapa kegiatan seperti layanan bimbingan dan konseling, minat dan bakat, pembinaan soft skills, beasiswa dan kesehatan. Dari layanan kegiatan inilah para mahasiswa dapat memberikan argumen dan menambah informasi serta memperoleh tujuan untuk memberikan sikap keterbukaan terhadap tim pengajar pendidikan yang ada.

Peneliti merasa perlu untuk dilakukannya tentang bagaimana persepsi dosen mengenai layanan kegiatan mahasiswa pada tahap pendidikan S1 Keperawatan di Fakultas Keperawatan Universitas Sumatera Utara

\section{Daftar Pustaka}

Alimul. (2002). Riset Keperawatan dan Teknik Penulisan Ilmiah.Penerbit Salemba Medika

Arikunto. (2006). Prosedur Penelitian Suatu Pendekatan Praktik edisi. Jakarta : PT. Rineka Cipta

Arikunto. (2009). Manajemen Penelitian. Jakarta :PT. Penerbit Rineka Cipta

BAN PT. (2008). http://banpt.kemdiknas.go.id. Borang Akreditasi Program Sarjana (4 April 2013)

Sitohang. Dewi Anggraini. (2009). Analisis harapan dan persepsi mahasiswa terhadap kualitas pelayanan administrasi pada departemen manajemen Fakultas Ekonomi USU. Medan : FAkultas Ekonomi Universitas Sumatera Utara.

(dipublikasikan di : http://repository. usu.ac.id/handle/123456789/30269pdf, diakses oleh Syaiful, 18 Mei 2013, jam 4.36 Wib).

Bahrul Kirom. (2012). Mengukur Kinerja Pelayanan dan Kepuasan Konsumen : Bandung Pustaka Reka Cipta

MIF Baihaqi, dkk. (2005). Psikiatri Konsep Dasar dan Gangguan-gangguan.
Hartono. (2010). Metode Penelitian. Penerbit Zanafa Publishing.

http://www.usu.ac.id/id/files/panduan/kepera watan.pdf, Panduan Perkuliahan S-1 Keperawatan (diakses oleh Syaiful. 4 April 2013 Jam 21.00 wib)

Nursalam. (2008). Konsep dan Penerapan Metodologi Penelitian Ilmu Keperawatan. Penerbit Salemba Medika

Rakhmat. (2004). Psikologi Komunikasi. Bandung : PT. Remaja Rosdakarya

Setiadi. (2007). Konsep \& Penulisan Riset Keperawatan. Penerbit Graha Ilmu

Sobur. (2003). Psikologi umum. Bandung : CV Pustaka Setia

Sunaryo. (2002). Psikologi untuk keperawatan. Penerbit buku kedokteran : EGC

UU RI No. 12 (2012). Pendidikan Tinggi 2012 Penerbit Sinara Grafika

Notoatmodjo, 2005. Metodologi Penelitian Kesehatan, Rineka Cipta, Jakarta. 
